\author{
(online) $=$ ISSN $2285-3642$ \\ ISSN-L = $2285-3642$ \\ Journal of Economic Development, Environment and People \\ Volume 3, Issue 3, 2014 \\ URL: http://jedep.spiruharet.ro \\ e-mail: office jedep@spiruharet.ro
}

\title{
The Municipality as a Source of Information?
}

\author{
Roman Vavrek $^{1 ⿴ 囗 十)}$, Ivana Kravčáková Vozárová, Martina Cehlárová, Ivana Ondrijová \\ ${ }^{1}$ University of Prešov in Prešov
}

\begin{abstract}
The municipality as an entity of the local government and disposes defined rights and obligations, which are governed by the special regulations. In accordance with Act no. 211/2000 Coll. on free access to information, the municipality is mandatory publish and make available information that this Act also more specify. This paper focuses on availability of information from websites or other available sources. The basic set was represented by 91 municipalities of Prešov district, in which were surveyed a total of 75 data 6 identification and 69 financial). Within the implemented questioning, we can conclude especially the availability of identification data, for which there are multiple sources (eg. number of inhabitants). Overall, however, the municipalities did not provide the requested information, when up to 27 municipalities did not provide more than 5 data (including 3 identification). One of the outcomes is also a proving of small correlation between the volume of data obtained from the municipality and the number of its inhabitants, respectively the distance from the district town.
\end{abstract}

Keywords: municipality, Act no. 211/2000 Coll., data, availability

JEL Codes: H70, H71

\section{Introduction}

The information and access to them are essential elements of democracy. They represent a way of control by the citizens. The information are not only the need for citizens - they are an essential part of a well-functioning community of people. To have information, to dispose of them at its own discretion and to control their disclosure, thus actually means to have the power. One of the entities to whom the law imposes a duty to disclose certain information is municipality. The communication with municipalities studied e.g. Dubéci (2013), who obtained the information regarding the number of received information requests and the number of rejected applications for the period 2010-2013 on a sample of 615 public and state administration entities (of which were 599 municipalities). He notes a small occupancy of the entities by duties required by law no. 2011/2000 Coll. on free access to information. He also recommended as one of the solutions to disclosure of frequently questioned information that would eliminate part of the administrative burden, which the municipalities and the entities of public and state administration face.

\footnotetext{
${ }^{+}$Corresponding author. Tel.: +421517775916 E-mail address: roman.vavrek@smail.unipo.sk.
} 


\author{
(online) $=$ ISSN $2285-3642$ \\ ISSN-L = 2285-3642 \\ Journal of Economic Development, Environment and People \\ Volume 3, Issue 3, 2014 \\ URL: $\underline{\text { http://jedep.spiruharet.ro }}$ \\ e-mail: office jedep@spiruharet.ro
}

The present contribution, after basic definition of municipality (including its scope and responsibilities) is dedicated to the results of our own survey. The aim of survey was to obtain a total of 75 data relating to economy of municipalities in the Prešov district.

\title{
2. The municipality and its position in the system of public administration
}

For public administration can be considered according Peková and Pilný (2002) a set of authorities and institutions of the state, whose performance is in the public interest. Public administration includes:

a) state administration, which has a dominant position,

b) self-administration, which is responsible for the performance of public administration

by applicable law, in particular:

$>$ at the level of local self-government, which is responsible for representing the interests of citizens living in a certain area smaller than the state;

$>$ at the level of self-interest administration.

Local self-government as one of the components of public administration was formed either naturally or artificially. Naturally as municipalities with a larger or smaller number of residents who lived on the same land. Artificially as a higher degree of local self-government at regional level. It includes the communities of the residents of more towns and villages in the given area that are associated with common interests in the locality (Provazníková 2009).

Provazníková (2009) and Peková (2011) for the functioning of local self-government consider the need to create these assumptions:

a) legislative (status, scope, competence, responsibility, functions, internal breakdown, relationships at the vertical level, etc..)

b) economic (ownership of property and the right to manage it, own resources, own budget, etc..).

The general definition the municipality as the basic unit of local self-government is based on the Constitution of the Slovak Republic (Act no. 460/1992 Coll.), which refers to other specific regulations. The Slovak constitution understands the municipality as an independent, territorial autonomous and administrative unit of the Slovak Republic associating persons who have a permanent residence in its territory. The Act on municipal establishment no. 369/1990 Coll. ( $\$ 1$ ) defines the municipality as "an independent, territorial autonomous and administrative unit of the Slovak Republic". It associates people who have residence in its territory. It is a legal entity that manages itself with its own property and its own income.

Mates and Wokoun (2001) regard the municipality as well as Wildmannová et al. (2001) for basic territorial self-governing community of citizens. They equally with Koudelka (2000) determined the territory and population for fundamental features of the municipality. As the last third characteristic of the municipality identified self-government respectively right to independence, which is implemented through a local referendum and municipal authorities. 


\author{
(online) $=$ ISSN $2285-3642$ \\ ISSN-L = 2285-3642 \\ Journal of Economic Development, Environment and People \\ Volume 3, Issue 3, 2014 \\ URL: $\underline{\text { http://jedep.spiruharet.ro }}$ \\ e-mail: office jedep@spiruharet.ro
}

For the characteristics of the municipality in addition to the above mentioned can be considered according to Mládková et al. (2011) the performance of self-government (independent scope of the municipality) and the performance of state administration (transferred scope of the municipality).

A slightly different view on the characteristics of the municipality offer Kadeřábková and Peková (2012), who state in addition to characters according Koudelka (2000) also the management of its own affairs (the so-called separate scope) and care about versatile development of the area.

The municipality can be seen also as a social organism which is defined geographically and is relatively stable. It is characterized by a set of dynamic features, which distinguish it from other forms of settlement (Toth 1998).

\title{
2.1. The scope of the municipality and its duties
}

When we define the scope, it is necessary to identify the difference between scope and competence. The scope is usually characterized as a kind of delegated tasks, respectively the circle of social relationships that the municipality may regulate. Inside this circle then the entity of the scope implements its competence, which we understand a set of instruments for fulfilling delegated tasks (Kadečka, 2009).

The scope according to Šebestová et al. (2008) represents a range of issues that an organization is competent to handle. The scope of the municipality is divided according to Wildmannová et al. (2001) into two levels:

a) separate scope,

b) transferred scope.

In accordance with Act no. 369/1990 Coll. on municipal establishment (unless a special act regulating performance of activities of municipalities do not provide that it is a transferred competence), it applies that it is a performance of separate (self-governinig) scope of the municipality.

The separate scope of the municipality includes administration of affairs, which are of the interest of the municipality and its citizens, unless they are conferred by statute of higher territorial units or unless it is transferred scope. Císařová and Pavel (2008) characterized a separate scope as a circle of activities carried out by municipalities under its own name and for the quality of these services are also responsible.

The transferred scope under Kadečka (2009) represents the deconcentrated state administration conferred to municipalities. In the transferred scope such municipality under the current legislation helps to state with the performance of his duties and competences. Wildmannová et al. (2001) add that performance of state administration in the transferred scope is not a law of the municipality, but its duty. View of the fact that the municipality pursues an activity in the transferred scope for the State, it receives the subsidy for its performance from the state budget. According to the Císařová and Pavel (2008), the transferred scope represents a range of activities carried out by municipality on behalf of the State. The State is also responsible for their quality.

According to Law no. 369/1990 Coll. the municipality conduct all actions related to the administration of the municipality and property. This law also describes the duties of the municipality, eg. the municipality prepares and approves the municipal budget and final account, directs an economic activity or provides public services. Union of towns of Slovakia (2013) considers as a national legislative framework of local selfgovernment (i.e. range of laws governing the activities of the municipality) 20 laws and 1 regulation, such 


\author{
(online) $=$ ISSN $2285-3642$ \\ ISSN-L = $2285-3642$ \\ Journal of Economic Development, Environment and People \\ Volume 3, Issue 3, 2014 \\ URL: $\underline{\text { http://jedep.spiruharet.ro }}$ \\ e-mail: office jedep@spiruharet.ro
}

as Act no. $369 / 1990$ Coll. on municipal establishment, Act no. 583/2004 Coll. on budgetary rules of local self-government, Act no. 564/1991 Coll. on the municipal police, Act no. 552/2003 Coll. on performance of work in public interest, Act. 564/2004 Coll. on budgetary determination of income tax revenue from local government, etc.

Act no. $211 / 2000$ Coll. on free access to information identifies the municipality as a person, who is obliged to disclose information under this law ( $\S 5, \S 5 a)$ and make available information on the management of public funds, the management of municipal property, environment, tasks or professional services related to the environment and information on content, performance and activities carried out under the concluded contract. The observance of provisions of this Act, i.e. obligatory disclosure and making available information by municipalities in practice is devoted the practical part of this present contribution.

\title{
3. Methodology
}

The absence of a central system (e.g. in the Czech Republic is a system UFIS/ARIS) creates a need to contact the municipality individually in the event of data. This process while maintaining the required conditions for further processing (in terms of statistical processing to achieve the desired confidence interval and significance level) is time-consuming and costly. In practice, there is a personal contacting of municipalities, contacting by email, telephone or questionnaire or using the existing websites. One option is also to use the Act no. 211/2000 Coll. on free access to information.

This paper is devoted to the case study, which aim was to obtain a total of 6 identification and 69 financial data relating to the financial management of municipalities in the Prešov district, namely local taxes and fees for the year 2013. Between the required data were:

a) identification data (e.g. number of inhabitants, the age of the mayor, the mayor's education);

b) financial data (e.g. expected real yields and local tax rates).

We contacted 91 municipalities, while the primary source were the websites of individual municipalities. Some municipalities were also contacted by email, in case of unavailability of data on its websites.

At the characteristics of the basic file were used selected torque characteristics that Markechová, Stehlíková, Tirpáková (2011) divided into 3 groups:

a) degree position (mode, median, average)

b) the degree of variability (standard deviation),

c) the degree of asymmetry (skewness coefficient, kurtosis coefficient). 


\author{
(online) $=$ ISSN $2285-3642$ \\ ISSN-L = 2285 - 3642 \\ Journal of Economic Development, Environment and People \\ Volume 3, Issue 3, 2014 \\ URL: http://jedep.spiruharet.ro \\ e-mail: office jedep@spiruharet.ro
}

In the next step was verified correlation between the selected data through Kendall-Stuart tau-c coefficient according to the formula:

$$
T_{c}=\frac{n_{c}-n_{d}}{n(n-1) / 2}
$$

where: nc-number of concordant pairs,

nd - number of discordant pairs.

The difference of mean values of the groups has been studied by means of Mann-Whitney $U$ test. The identified data were collected over a period from May to July 2014. The environment for processing of results as well as other intermediate calculations were provided by MS Office 2007 and the program Statistica 12.

\title{
4. Results and discussion
}

In all municipalities were available 3 identification indicators from the total number of 75 monitored indicators (population, distance from the town and gender of the mayor). These 3 variables represents a minimum of obtained data of two municipalities and thus in these two municipalities in the Prešov district, the data have not been detected by chosen methods. $29.67 \%$ of municipalities have provided maximum 5 data (including 3 identification). The most numerous group were group of municipalities, which provided a maximum of 5 to 20 data. This group consisted of 27 municipalities. The maximum number of detected data was 27 (36\% of the total), while such number of data was provided by the 3 municipalities.

In this described file were measured median 19 data, average 15.89 data and modus 5 data. The skewness coefficient at the level -0.532 indicates that more remote values occur on the left from the average (creation the so-called left tail). The distribution is flatter than a normal distribution (kurtosis coefficient is at the level -1.29$)$.

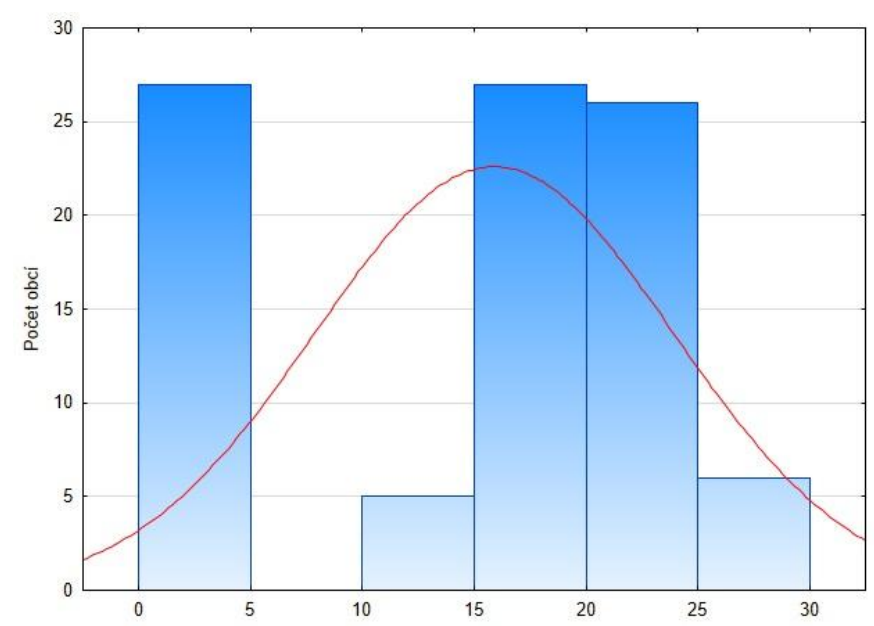

Fig.1: The frequency of municipalities in the individual groups according to the number of detected data Source: Own calculations 


\author{
(online) $=$ ISSN $2285-3642$ \\ ISSN-L = 2285 - 3642 \\ Journal of Economic Development, Environment and People \\ Volume 3, Issue 3, 2014 \\ URL: http://jedep.spiruharet.ro \\ e-mail: office jedep@spiruharet.ro
}

From the perspective of the availability of selected data can be reported unavailability especially financial data. 5 identification data ( 6 searched) were detected in at least $82.41 \%$ of municipalities of the basic file. The age of mayor was possible to find only in $30 \%$ of municipalities.

From the financial indicators, the rate of individual items of the land tax was available in 63 (respectively 62) municipalities. These were divided into 6 subgroups in accordance with Act no. 582/2004 Coll. on local taxes and local fees for municipal waste and minor construction waste.

A total of 48 from the 75 searched data were "de facto" undetectable. This group included e.g. total revenue from land tax or tax on buildings, expected and actual revenue of the different kinds of local taxes.

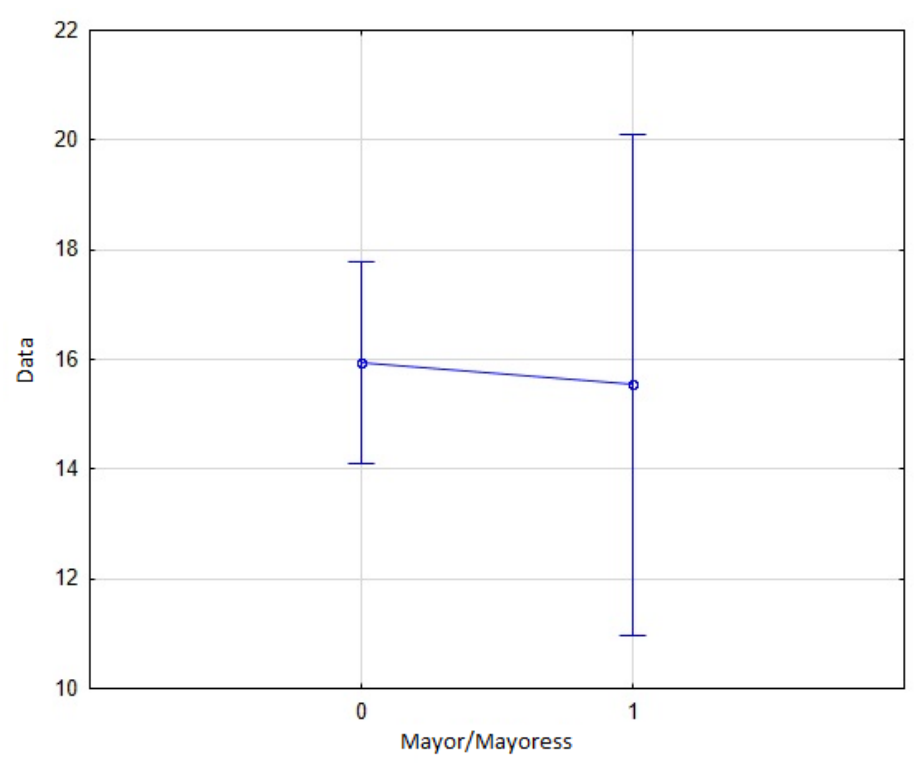

Fig. 2: Availability of data related to gender of mayors

Source: Own processing

While watching of results (number of obtained data from municipalities) in relation to the fact whether is at the head of the municipality man or woman, we can follow the following differences:

a) 15 respectively 16 data were available in average in both groups of municipalities;

b) marginal values were almost identical (min. 3, max. 26/27);

c) significant difference can be observed at the lower quantile (males - 5 females - 14), at the upper kvantile was the difference in one data;

d) 78 municipalities in the Prešov district has a man as the mayor, 13 municipalities has a woman as the mayor. 


\author{
(online) $=$ ISSN $2285-3642$ \\ ISSN-L = $2285-3642$ \\ Journal of Economic Development, Environment and People \\ Volume 3, Issue 3, 2014 \\ URL: $\underline{\text { http://jedep.spiruharet.ro }}$ \\ e-mail: office jedep@spiruharet.ro
}

On the surface $p \leq 0.05$ was not confirmed the significant difference between the measured mean values by Mann-Whitney $U$ test. The correlation between the selected cardinal variables was monitored by Kendall-Stuart tau-c coefficient, which identified at the significance level $p \leq 0,05$ :

a) small correlation $(\mathrm{TC}=0.214$ ) between the number of inhabitants and the number of available data;

b) small negative correlation ( $\mathrm{TC}=-0.147$ ) between the number of available data and the distance of the municipality from the district town (in this case of Prešov).

\title{
5. Conclusion
}

The data availability constitutes an essential factor that determines the possible results of each survey and research. In our research, we contacted 91 municipalities of the Prešov district, in which we examined a total of 75 data, including 6 identification and 69 financial. On the basis of measured results, we can conclude the low data availability in all municipalities. The maximum number of obtained data in one municipality was 27 . This number includes all monitored identification data, which can be considered as the basic geographic data (e.g. number of inhabitants). One of the ways to improve access to information is their disclosure e.g. on the website. It is also possible (after considering the time and financial possibilities) to change the methodology in obtaining data for increasing the number obtained data.

The majority group of municipalities is headed by a man and there is not possible to observe the negative/positive impact on the number of available data. By applying of selected statistical methods was confirmed only a small correlation between the number of inhabitants, respectively distance from the district town and the number of available data, which are not considered as significant.

A separate chapter is the amendment to Act no. 431/2002 Coll. on accounting ( $\S 23$ to $\S 23 \mathrm{~d}$ ), which introduced new provisions on register of financial statements. Into the register of financial statements (hereinafter "RUZ") are stored the financial statements, which are compiled to the 31st December 2013 and at a later date. Since 2014, the entities have an obligation to store of financial statements to RUZ, which subsequently will ensure their deposit into the collection of documents of Business Register. The mandatory publication of information in the RUZ ensured the access to obtaining the basic information on the activities of the municipality in the past. On the basis of carried survey, we must also conclude that the available are data for the whole, not partial data that were followed.

There are not also accessible information on the current (not all municipalities meet the obligations under the Act no. 211/2000 Coll., i.e. they do not disclosed the obligatory published contracts) and future planned activity of the municipality.

\section{Acknowledgements}

The study is a partial output of the research project GAMA/14/3.

\section{References}

[1] E. Císařová, and J. Pavel. Prưvodce komunálními rozpočty aneb jak může informovaný občan střežit obecní pokladnu. Praha: Transparency International, 2008. 94 p. ISBN 978-80-87123-06-5. 


\author{
(online) $=$ ISSN $2285-3642$ \\ ISSN-L = 2285 - 3642 \\ Journal of Economic Development, Environment and People \\ Volume 3, Issue 3, 2014 \\ URL: http://jedep.spiruharet.ro \\ e-mail: office jedep@spiruharet.ro
}

[2] S. Kadečka. Kapitoly ze správniho práva III - Organizace veřejné správy. ASPI - LIT20486CZ, 2003.

[3] J. Kadeřábková, and J. Peková. Územní samospráva - udržitelný rozvoj a finance. Praha: Wolters Kluwer ČR, 2012. 300 p. ISBN 978-80-7357-910-4.

[4] Z. Koudelka. OBCE A KRAJE podl'a reformy veřejné správy v roce 2000. Praha: LINDE PRAHA, 2000. 228 p. ISBN $80-$ 7201-250-9.

[5] D. Markechová, B. Stehlíková, and B. Tirpáková. Štatistické metódy a aplikácie. Nitra: Univerzita Konštantína filozofa v Nitre, 2011. 534 p. ISBN 978-80-8094-807-8.

[6] R. Mates, and R. Wokoun et al. Malá Encyklopedie regionalistiky a veřejné správy. Praha: PROSPEKTRUM, 2001. 200 p. ISBN 80-7175-100-6.

[7] L. Mládková et al. Vybrané aspekty systému řízení státních organizací. Zlín: VeRBuM, 2011. 124 p. ISBN 978-8087500-10-1.

[8] J. Peková. Verejné finance: teorie a prax v ČR. Praha: Wolters Kluwer ČR, 2011. 644 p. ISBN 978-80-7357-698-1.

[9] J. Peková, and J. Pilný. Veřejná správa a finance veřejného sektoru. Praha: ASPI Publishing, 2002. 442 p. ISBN 8086395-21-9.

[10] R. Provazníková. Financování měst, obcí a regionů: teorie a praxe. Praha: GRADA Publishing, 2009. 304 p. ISBN 978-80-247-2789-9.

[11] J. Šebestová. Kontrolní systém veřejné správy a veřejného sektoru. Karviná: Slezská univerzita v Opavě, 2008.180 p. ISBN 978-80-7248-460-7.

[12] J. Toth. Ekonomika měst a obcí. Praha: Grada, 1998. 194 p. ISBN 80-7079-693-6.

[13] Únia miest Slovenska. 2013. [online]. cited 5th september 2014. Available at: <http://www.unia-miest.sk/vismo/zobraz_dok.asp?id_org=600175\&id_ktg=1065\&p1=1267>.

[14] M. Wildmannová et al. Územní samospráva v ČR, Rakousku a SRN. Brno: Masarykova univerzita v Brne, 2001.139 p. ISBN 80-210-2514-X.

[15] Act no. 369/1990 Coll. on municipal establishment

[16] Act no. 460/1992 Coll. Constitution of the Slovak Republic

[17] Act no. 211/2000 Coll. on free access to information

[18] Act no. 431/2002 Coll. on accounting 